\title{
Niezgodności złączy lutowanych spoiwami twardymi i przyczyny ich powstawania
}

\section{Imperfections in brazed joint and sources of their formation}

\section{Streszczenie}

Omówiono rodzaje niezgodności lutowniczych oraz fizykochemiczne i technologiczne przyczyny ich powstawania. Scharakteryzowano również normę PN-EN ISO 18279 Lutowanie twarde - niezgodności w złączach lutowanych na twardo.

\section{Abstract}

Types of brazing imperfections and physical, chemical and technological sources of their formation have been presented. Additionally PN-EN ISO 18279 Brazing - imperfections in brazed joints standard has been discused.

\section{Wstęp}

Podczas lutowania twardego, a więc lutowania spoiwami o temperaturze topnienia wyższej niż $450^{\circ} \mathrm{C}$ (723 K), nie dochodzi przetapiania brzegów łączonych materiałów, lecz tylko ich nagrzania do temperatury lutowania i stopienia spoiwa (lutu). Połączenie lutowane powstaje w tych warunkach w wyniku występujących zwykle kompleksowo zjawisk charakterystycznych dla teorii kapilarności (zwilżenie materiału łączonego przez lut, rozpływanie się lutu po powierzchniach łączonych materiałów, wnikanie kapilarne lutu w szczelinę złącza) i w wyniku oddziaływania rozpuszczeniowo-dyfuzyjnego pomiędzy ciekłym lutem i materiałem łączonym w stanie stałym. Jeżeli oddziaływanie między lutem i materiałem łączonym ogranicza się wyłącznie do zjawisk kapilarnych, powstaje połączenie bezdyfuzyjne typu adhezyjnego. Efektem procesu lutowania jest lutowina utworzona w części centralnej ze stopiwa lutowniczego, powstałego ze stopionego spoiwa - lutu (może zawierać również składniki materiałów łączonych) i obejmująca od strony materiałów łączonych

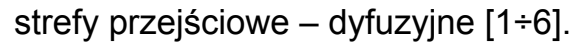

Ta odmienność procesów fizykochemicznych stanowiących podstawę tworzenia połączeń lutowanych $\mathrm{w}$ porównaniu $\mathrm{z}$ połączeniami spawanymi

Dr inż. Andrzej Winiowski - Instytut Spawalnictwa, Gliwice.

i zgrzewanymi powoduje, że również niezgodności lutownicze mają nieco odmienny charakter od niezgodności spawalniczych i zgrzewalniczych. Dotyczy to również lutozgrzewania i lutospawania (gazowego, łukowego, laserowego i wiązką elektronów).

W artykule przedstawiono typowe niezgodności lutownicze i podstawowe przyczyny ich powstawania, a także komentarz do stosowania obowiązującej normy PN-EN ISO 18279 Lutowanie twarde. Niezgodności w złączach lutowanych na twardo.

\section{Rodzaje niezgodności w połączeniach lutowanych lutami twardymi i przyczyny ich powstawania}

Niezgodności lutownicze występujące w połączeniach wykonanych przez lutowanie twarde można podzielić na następujące rodzaje:

- pęknięcia,

- pustki,

- wtrącenia stałe,

- brak połączenia,

- niezgodności kształtu i wymiarów,

- inne niezgodności.

Niezgodności te dzieli się na: zewnętrzne - powierzchniowe, które obejmują: pęknięcia (powierzchniowe), porowatość powierzchni lutowiny, niezgodności 
kształtu i wymiarów złącza, przetopienie miejscowe, chropowatość powierzchni lutowiny, wniknięcie topnika w powierzchnię lutowiny i jego pozostałości na złączu, rozprysk lutu, barwy nalotowe (cieplne), erozję powierzchni materiałów łączonych itp; wewnętrzne, takie jak: pęknięcia (wewnętrzne), brak połączenia, wtrącenia stałe (metaliczne, tlenkowe, topnikowe), pustki gazowe, przyklejenie lutowiny, skutki nadmiernego przereagowania spoiwa $\mathrm{z}$ materiałem

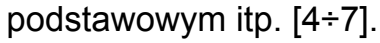

\section{Pęknięcia lutownicze}

Pęknięcie lutownicze definiuje się zwykle jako ograniczone rozdzielenie materiału w wyniku występowania naprężeń rozciągających. Pęknięcia mogą być ułożone podłużnie lub poprzecznie względem osi złącza i występować w lutowinie lub na jej granicy (w stopiwie lutowniczym lub w strefie dyfuzji), a także w strefie wpływu ciepła $w$ materiale łączonym oraz $w$ materiale łą-

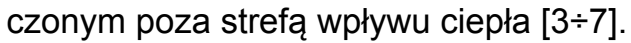

Ze względu na mechanizm powstawania, pęknięcia w połączeniach lutowanych dzieli się na zimne, powstające podczas chłodzenia połączenia lutowanego w temperaturze do ok. $200^{\circ} \mathrm{C}$, i gorące, występujące w wyższych temperaturach. Przyczyną zimnych pęknięć, występujących na ogół w obrębie lutowiny w stopiwie lutowniczym lub w strefach dyfuzyjnych złącza, jest najczęściej powstawanie w strukturze złącza kruchych faz międzymetalicznych i mieszanin eutektycznych (rys. 1). Pęknięcia te mogą być także wynikiem zbyt szybkiego chłodzenia złącza po lutowaniu wskutek dużej różnicy rozszerzalności cieplnej między łączonymi materiałami lub lutowiną (lutem) i łączonym materiałem.

Pęknięcia gorące, występujące czasem w lutowinach w stopiwie lutowniczym, powstają na ogół w procesie krystalizacji lutowiny lub poniżej jej temperatury solidusu podczas poligonizacji granic ziaren. Bezpośrednią przyczyną tych pęknięć jest zbyt mała (przy stosunkowo wysokich naprężeniach podczas

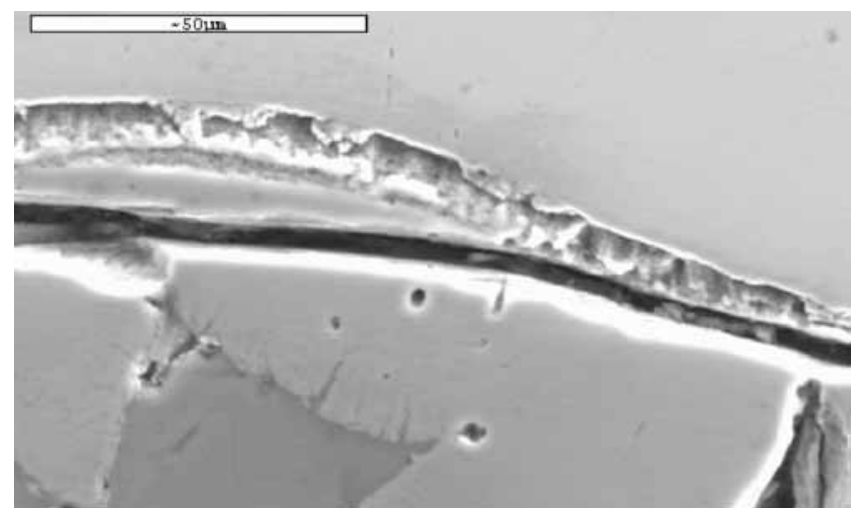

Rys. 1. Pęknięcie zimne pomiędzy kruchymi fazami w połączeniu stal nierdzewna (góra) - tytan (dół), lutowanym spoiwem srebrno-miedzianym w próżni. Traw. odczynnikiem Buehler

Fig. 1. Cold crack between brittle phases in stainless steel (up) - titanium (down) joint brazed with silver - cooper filler metal in vaacum. Etch. Buehler krzepnięcia) wytrzymałość i zdolność do odkształcenia lutowiny lub występujących w niej niżej topliwych faz. Szczególnie narażone na takie pęknięcia są lutowiny wykonane wieloskładnikowymi spoiwami o szerokim zakresie krystalizacji.

Pęknięcia w materiale lutowanym powstają najczęśściej przy lutowaniu materiałów o małej plastyczności i rozszerzalności cieplnej. Ich przyczyną może być również dyfuzja lutu do materiału łączonego, np. w warunkach słabej rozpuszczalności lutu w tym materiale.

\section{Pustki}

Niezgodności tego typu obejmują: drobne i obszerne pęcherze gazowe (powierzchniowe, pojedyncze lub grupowe w postaci gniazd lub łańcuchów) oraz pory powierzchniowe.

Ze względu na mechanizm powstawania pęcherze i pory w połączeniach lutowanych można podzielić na:

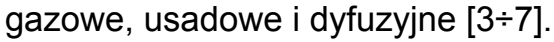

Pęcherze gazowe powstają najczęściej w wyniku miejscowego braku zwilżenia powierzchni materiału łączonego przez ciekły lut, wydzielania się gazów z ciekłej lutowiny przy krzepnięciu (wraz z obniżeniem temperatury zmniejsza się rozpuszczalność gazów), a niekiedy również w wyniku odgazowania materiałów łączonych w strefie przyległej do lutowiny (rys. 2). Mogą też powstawać podczas nagrzewania z zanieczyszczeń organicznych i tlenkowych na powierzchniach łączonych materiałów oraz w wyniku miejscowego odparowania lutu i topnika lub ich składników o niskich temperaturach wrzenia.

Pęcherze (pustki) usadowe powstają niekiedy w przestrzeniach międzydendrytycznych przy krzepnięciu lutowin, wykonanych lutami o bardzo szerokim zakresie krzepnięcia.

Pęcherze (pustki) dyfuzyjne powstają natomiast w wyniku nierównomiernej dyfuzji składników (np. efektu Kirkendalla) w złączu w procesie jego powstawania lub podczas wyżarzania ujednoradniającego (dotyczy to np. homogenizacji połączeń lutowanych dyfuzyjnie), czy też w eksploatacji połączeń lutowanych w wysokiej temperaturze.

Występowaniu pęcherzy (pustek) w połączeniach lutowanych sprzyjają też: zbyt wysoka temperatura i długi czas lutowania, nierównomierne nagrzanie złącza lub wadliwa konstrukcja połączeń, uniemożliwiająca całkowite wypchnięcie przez ciekły lut na zewnątrz powietrza ze szczeliny lutowniczej.

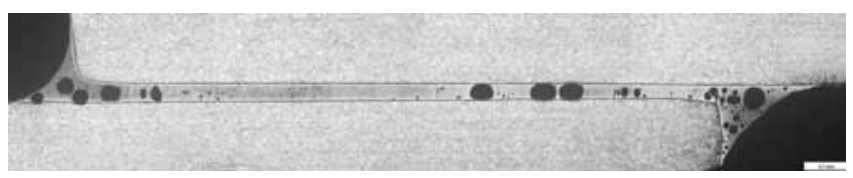

Rys. 2. Pęcherze gazowe w połączeniu elementów mosiężnych lutowanych spoiwem srebrnym i topnikiem fluorkowym. Traw. $\mathrm{FeCl}_{3}$ Fig. 2. Gas pore in joint of braze elements brazed with silver filler metal and fluoride flux. Etch. $\mathrm{FeCl}_{3}$ 


\section{Wtrącenia stałe}

Wtrącenia stałe, występujące w lutowinach, mogą być niemetaliczne i metaliczne. Do pierwszych należą przede wszystkim wtrącenia tlenkowe i topnikowe, a do drugich wtrącenia obcych metali $[3 \div 7]$.

Wtrącenia tlenkowe (tlenki z powierzchni materiałów łączonych) występują zwykle na granicach lutowiny. Ich źródłem są źle oczyszczone powierzchnie łączonych materiałów. W wyniku reakcji metalurgicznych pomiędzy reaktywnymi składnikami lutów i gazami $z$ atmosfery w lutowinie mogą powstawać również wtrącenia węglików i azotków.

Wtrącenia topnikowe (topnik, żużel topnikowy) występują w lutowinie lub na jej powierzchni w przypadku stosowania zbyt niskiej temperatury lub zbyt krótkiego czasu lutowania, niewłaściwego dozowania lutu (np. z obydwu stron) do szczeliny lutowniczej złącza, stosowania topników o zbyt dużej gęstości w porównaniu $z$ gęstością ciekłego lutu oraz zastosowania zbyt małych szczelin lutowniczych w złączach. Powstawaniu takich wtrąceń sprzyja nadmiar topnika lutowniczego.

Wtrącenia obcych metali mogą pochodzić z zewnątrz, np. z elementów oprzyrządowań mocujących i ustalających położenie łączonych części.

\section{Brak połączenia}

Niezgodności tego typu obejmują: przyklejenie lutowiny, a więc brak lub niedostateczne połączenie o ciągłości fizycznej pomiędzy materiałem łączonym i lutowiną, miejscowy brak wypełnienia lutem szczeliny złącza oraz niedolutowanie, tj. niepełne wniknięcie lutu do

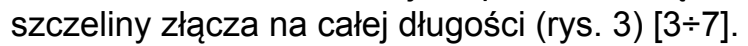

Pierwsza z tych niezgodności, przyklejenie lutowiny, jest powodowana zwykle brakiem właściwego zwilżenia przez lut jednej lub obu powierzchni łączonych materiałów. Sprzyja temu utleniona lub zanieczyszczona substancjami organicznymi powierzchnia łączonego materiału, mała aktywność topnika lub atmosfery kontrolowanej w procesie lutowania, zbyt mała ilość topnika, a także za niska temperatura i zbyt krótki czas lutowania.

Przyczyną braku wypełnienia lutem szczeliny złącza oraz niedolutowania może być np.: zastosowanie zbyt małej lub zbyt dużej szczeliny lutowniczej, czy też zbyt szerokiej zakładki złącza. Może też wynika $z$ zastosowania zbyt małej ilości lutu (zwłaszcza

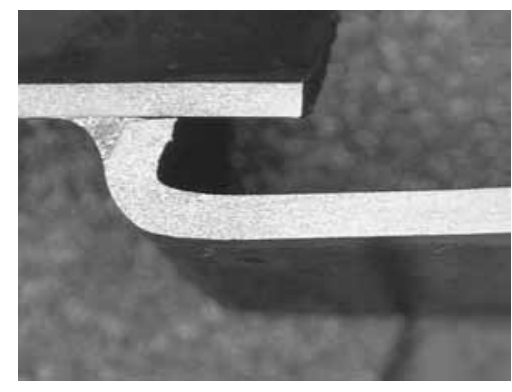

Rys. 3. Niedolutowanie w złączu mosiężnym lutowanym spoiwem srebrnym i topnikiem fluorkowym. Traw. $\mathrm{FeCl}_{3}$

Fig. 3. Incomplete penetration in braze joint brazed with silver filler metal and fluoride flux. Etch. $\mathrm{FeCl}_{3}$ niedolutowania) lub topnika, a także niskiej temperatury (niedogrzania części) i krótkiego czasu lutowania.

\section{Niezgodności kształtu i wymiaru złącza}

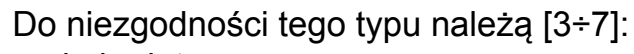 \\ - nadmiar lutu, \\ - niezgodności kształtu złącza, \\ - liniowe przemieszczenie elementów złącza, \\ - kątowe przemieszczenie elementów złącza, \\ - odkształcenie złącza, \\ - miejscowe stopienie/przetopienie wskośne złącza \\ lub materiału łączonego w przyległym obszarze, \\ - nadtopienie powierzchni łączonego materiału, \\ - erozja powierzchni złącza w wyniku agresywnego \\ oddziaływania lutu, \\ - chropowatość powierzchni złącza, \\ - niedomiar lutu/wklęsła wypływka pochwinowa \\ (pachwina) lutowiny, \\ - niedostateczna wypływka pochwinowa (pachwina) \\ lutowiny, \\ - nieregularna wypływka pochwinowa (pachwina) lu- \\ towiny. \\ Przyczyn tych niezgodności należy upatrywać
} w zastosowaniu zbyt dużej ilości lutu lub jego niewłaściwej postaci, niedostatecznym ustaleniu położenia elementów lutowanych, źle zaprojektowanym oprzyrządowaniu pomocniczym do lutowania (liniowe i kątowe przemieszczenie elementów, odkształcenie złącza), czy też doprowadzeniu nadmiernej ilości ciepła w wyniku źle dobranego źródła ciepła przy lutowaniu. Powodami mogą być również: zbyt wysoka temperatura i długi czas lutowania, brak wprawy w operowaniu źródłem ciepła przy lutowaniu ręcznym (miejscowe stopienie lub przetopienie, nadtopienie powierzchni, erozja), zbyt mała ilość lutu, zbyt szeroka szczelina lutownicza (niedomiar lutu - wklęsła pachwina)), niedostateczne warunki zwilżania, żle dobrany topnik lutowniczy, niedogrzanie lub przegrzanie złącza (chropowatość powierzchni), czy też nieregularne krzepnięcie i likwacja w lutowinie (chropowatość powierzchni, nieregularna lub niedostateczna pachwina).

\section{Inne niezgodności}

Trzeba też zauważyć niezgodności, które nie są sklasyfikowane w przedstawionych powyżej grupach.

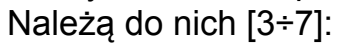

- odpryski lutu na powierzchni łączonych elementów,

- cieplne barwy nalotowe (utlenienie) na powierzchni złącza,

- wtrącenia lub pozostałości topnika nieusunięte ze złącza po lutowaniu,

- nadmierne rozpłynięcie lutu, ślady trawienia materiału łączonego przez topnik. 
Przyczyny powstawania tych niezgodności przedstawiono już wcześniej. I tak, do podstawowych przyczyn powstawania odprysków lutu na powierzchniach materiałów łączonych należy zagazowanie i zawilgocenie lutu lub topnika oraz jednoczesne przegrzanie lutu i niedogrzanie materiału łączonego. Cieplne barwy nalotowe i utlenienie złączy mogą być wywołane niedostateczną osłoną topnikową lub zanieczyszczoną atmosferą kontrolowaną w procesie lutowania. Nadmierne przereagowanie lutu z materiałami łączonymi może nastąpić w przypadku dostarczenia nadmiernej ilości ciepła do złącza, stosowania zbyt długiego czasu lutowania lub zbyt dużej ilości lutu. Ważna jest również wysoka skłonność lutu i materiału łączonego lub ich składników do intensywnego oddziaływania fizykochemicznego. Przyczyną wtrąceń i pozostałości topnikowych na powierzchni lutowiny może być źle dobrany topnik, jego nadmiar, a także zbyt niska temperatura oraz krótki czas lutowania. Nadmierne rozpłynięcie lutu może natomiast wystąpić po przegrzaniu łączonych elementów lub jednego z nich, a także w przypadku zastosowania nadmiaru lutu i topnika. Występowaniu tego zjawiska sprzyja chropowata powierzchnia łączonego materiału (np. po zgrubnej obróbce skrawaniem), której nierówności stanowią kapilarne mikroszczeliny dla ciekłego lutu.

\section{Klasyfikacja niezgodności lutowniczych wg PN-EN ISO 18279:2008 i poziomy jakości połączeń lutowanych}

W normie PN-EN ISO 18279 Lutowanie twarde Niezgodności w złączach lutowanych na twardo przedstawiono rodzaj, kształt i położenie niezgodności lutowniczych.

Niezgodności lutownicze są definiowane jako „nieprawidłowości w złączu lutowanym, a także przemieszczenie się elementów lutowanych względem zamierzonej pozycji i kształtu podzespołu lutowanego, gdy przemieszczenie to zależy tylko od lutowania".

Wszystkie niezgodności lutownicze sklasyfikowano w sześciu grupach: pęknięcia (grupa I), pustki (grupa II), wtrącenia stałe (grupa III), brak połączenia (grupa IV), niezgodności kształtu i wymiarów (grupa V), niezgodności różnorodne (grupa VI). Dalsze rozróżnienie jest dokonane pomiędzy zewnętrznymi i wewnętrznymi niezgodnościami, które występują w połączeniach lutowanych.

W normie PN-EN ISO 18279 podano również proponowane dla poszczególnych typów niezgodności granice ich występowania w celu określenia poziomów jakości połączeń lutowanych. Ustalono trzy poziomy jakości połączeń lutowanych, wyznaczających wymagania: D - umiarkowany, C - pośredni, B - ostry.
Przewidziano jeszcze poziom A przeznaczony dla szczególnie ostrych wymagań w specjalistycznych zastosowaniach lutowania.

W zakresie tej klasyfikacji poziomów jakości połączeń lutowanych autorzy normy zwracają uwagę na ograniczoną możliwość jej zastosowania [8]. Zastosowanie poziomów jakości dla złączy lutowanych może być skuteczne bowiem tylko wtedy, kiedy jest określony wpływ wykazanych niezgodności na eksploatację złączy. W złączach lutowanych występują niezgodności, które są uznawane za szkodliwe w każdym przypadku lub też uznawane za szkodliwe lub nieszkodliwe w różnych przypadkach zastosowań, w zależności od wymagań eksploatacyjnych stawianych złączom. Ocena wpływu wymienionych niezgodności na funkcjonowanie złączy podczas eksploatacji jest trudna, gdyż nie prowadzono dotychczas wiarygotnych badań w tym zakresie, jak np. dla złączy spawanych.

Korzystając z praktycznych doświadczeń przemysłowych, w normie PN-EN ISO 18279 klasyfikującej szczegółowo niezgodności lutownicze w złączach lutowanych lutami twardymi, podjęto próbę określenia poziomów jakości i przedstawienia proponowanych granic tych niezgodności jedynie dla ogólnych zastosowań. Należy je jednak traktować jako propozycje, które mogą być przydatne, gdy brak jest innych szczegółowych przepisów w tym zakresie.

Wymagania dotyczące funkcjonowania złączy odpowiedzialnych i ważnych konstrukcji lutowanych zaleca się określać, korzystając z odpowiednich dokumentów, np. dokumentacji produkcyjnej lub instrukcji technologicznej wytwarzania.

Jest również ważne, aby wymagania stawiane poszczególnym złączom lutowanym były szczegółowo przedstawione oraz w pełni udokumentowane przed każdym przystąpieniem do klasyfikacji i w związku z tym możliwe do weryfikacji. Spełnienie tych wymagań może być sprawdzane przez badanie albo samego złącza lutowanego, lub też odpowiedniej próbki wytworzonej w warunkach porównywalnych do produkcyjnych.

Nie można jednak pominąć uwag krytycznych do tej ważnej i potrzebnej normy, dotyczących tłumaczenia na język polski niektórych nazw niezgodności, dokonanych przez weryfikatorów w Polskim Komitecie Normalizacyjnym, niezależnie od Komitetu Technicznego, w którym ta norma była tłumaczona. I tak, „niedolutowanie” niewłaściwie występuje w niej jako „brak przetopu” (!), „brak wypełnienia lutem szczeliny złącza” jako „niezgodności materiału wypełniającego”, „nadmiar lutu” jako „nadmiar lutowiny twardej”, „nieregularna lub niedostateczna wypływka pachwinowa (pachwina) lutowiny” jako „niewystarczające lub nieregularne zaokrąglenie”, „cieplne barwy nalotowe” jako „zmiana barwy”, „wtrącenie topnikowe” jako „wyciek topnika”, „nadmierne rozpłynięcie lutu” jako „nadmierne rozpłynięcie lutowiny twardej" itp. 


\title{
Literatura
}

[1] Praca zbiorowa: Brazing Handbook. AWS, Miami, Florida, 2007.

[2] Schwartz M.: Brazing. ASM International, Material Park, Ohio, 2003.

[3] Laško N.F., Laško S.V.: Pajka metałłov. Mašinostrojenie, Moskva, 1984.

[4] Praca zbiorowa: Spravočnik po pajkie. Mašinostrojenie, Moskva, 2003

[5] Pietrunin J.E.: Fiziko-chimičeskije processy pri pajkie. Wysšaja Škoła, Moskva, 1972

[6] Pietrunin I.E., Markowa I.J., Jekatowa A.S.: Metałłowiedenie pajki. Metałłwurgia, Moskwa 1978.

[7] Czuchryj J., Papkala H., Winiowski A.: Niezgodności w złaczach spajanych. Skrypt Instytutu Spawalnictwa. Gliwice, 2005.

[8] Łomozik M., Pietras A., Stano S., Węglowska A., Węglowski M., Winiowski A.: Makroskopowe i mikroskopowe badania metalograficzne materiałów konstrukcyjnych i ich połączeń spajanych. Skrypt Instytutu Spawalnictwa. Gliwice, 2009.

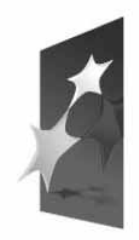

KAPITAŁ LUDZKI

NARODOWA STRATEGIA SPÓJNOŚCI

UNIA EUROPEJSKA
EUROPEJSKI

FUNDUSZ SPOLECZNY

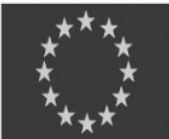

Projekt współfinansowany ze środków Unii Europejskiej w ramach Europejskiego Funduszu Społecznego

\section{"Kursy zawodowe, metodą MAG i TIG - szansą zdobycia dobrego zawodu" Szkolenia spawalnicze dla osób niepełnosprawnych}

\author{
Jesteś osobą niepełnosprawną? \\ Pragniesz doskonalić swoje umiejętności i zdobyć kwalifikacje zawodowe \\ najbardziej poszukiwane na Opolszczyźnie?
}

Dzięki wsparciu z Europejskiego Funduszu Społecznego możesz skorzystać z darmowych szkoleń zawodowych z zakresu spawania metodami MAG 135 i TIG 141, będącymi jednymi z najbardziej poszukiwanych na Opolszczyźnie kwalifikacji.

Organizator szkolenia zapewnia: wyżywienie i materiały dydaktyczne.

Do udziału w szkoleniach szczególnie zapraszamy kobiety.

Więcej informacji w Biurze Projektu w Opolu, ul. Kępska 3-5, pod numerem telefonu: 510265115 oraz na stronie: www.profesja1.pl

To twoja szansa na lepsze jutro, czy stać Cię, by ją zmarnować? 